\title{
FAKTOR KUNCI KEBERHASILAN RITEL MODERN DI INDONESIA
}

\author{
Harmon Chaniago ${ }^{1,}$ Iwan Mulyawan ${ }^{2}$, Tintin Suhaeni ${ }^{3}$, Rahil Jumiyani ${ }^{4}$ \\ 1) Jurusan Adm. Niaga, Politeknik Negeri Bandung, Bandung, Indonesia \\ Email: harmon@polban.ac.id \\ 2) Jurusan Adm. Niaga, Politeknik Negeri Bandung, Bandung, Indonesia \\ Email: mulyawaniwan93@gmail.com \\ 3)Jurusan Adm. Niaga, Politeknik Negeri Bandung, Bandung, Indonesia \\ Email: tintin.suhaeni@polban.ac.id \\ 4)Jurusan Teknik Komputer, Politeknik Negeri Bandung, Bandung, Indonesia \\ Email: rahil@jtk.polban.ac.id
}

\begin{abstract}
Abstrak
Penelitian ini bertujuan mencari faktor kunci keberhasilan ritel modern kelompok minimarket dan faktor apa yang menjadi daya tarik bagi konsumennya. Objek penelitian adalah semua ritel modern/minimarket dan beroperasi di Kota Cimahi, Jawa Barat. Sedangkan subjek penelitiannya adalah semua konsumen ritel tersebut. Total konsumen menjadi responden ada 388 responden. Untuk mendapatkan hasil maksimal, digunakan metode penelitian deskriptif dengan pendekatan kuantitatif. Analisis data memakai analisis faktor, uji ratarata dan test rank. Hasil penelitian diperoleh informasi ada 10 faktor penentu keberhasilan ritel modern, yaitu: strategi bisnis ritel, tampilan fisik ritel, citra ritel, merchandise \& assortment, komunikasi yang dipercaya, efektivitas teknologi pembayaran, customer service, media promosi, profesional SDM, jaminan pembayaran. Faktor dominan penentu keberhasilan ritel modern berupa efektivitas penggunaan teknologi pembayaran dan tampilan fisik toko/ritel. Faktor tersebut adalah kunci yang menyebabkan ritel modern disukai konsumen.
\end{abstract}

Kata kunci: ritel modern, faktor kunci keberhasilan ritel modern, daya tarik ritel.

\begin{abstract}
The study aims to find the key factors for the success of modern retail in minimarket groups and what factors are attractive for consumers. The research objects are all modern retail/minimarket and operate in Cimahi City, West Java. While the research subjects are all consumers of the modern retail. Total consumers became respondents there were 388 respondents. To get maximum results, descriptive research methods with quantitative approaches are used. Data analysis used factor analysis, rank test and mean analysis. The research results obtained information that there are 10 determinants of modern retail success, namely: retail business strategy, retail physical appearance, retail image, merchandise \& assortment, trusted communication, payment technology effectiveness, customer service, promotional media, HR professionals, payment guarantees. The dominant factor determining the success of modern retailers is the effectiveness of the use of payment technology and the physical appearance of the retail. These factors are the key that causes modern minimarket favored by consumers
\end{abstract}

Key words: modern retail, the key success factors for minimarkets, retail attractiveness.

\section{Pendahuluan}

Salah satu bentuk perdagangan yang banyak dilakukan oleh masyarakat adalah bisnis ritel. Ada dua bentuk bisnis ritel dijalankan oleh masyarakat, yaitu bisnis ritel tradisional dan bisnis ritel modern.
Bisnis ritel tradisional berupa toko-toko yang menjual kebutuhan harian masyarakat, dijalankan oleh perorangan sesuai keingingan dan pengetahuan dari pemilik (Sujana, 2012). Sedangkan bisnis ritel modern dijalankan oleh perorangan/kelompok pengusaha. Panigyrakis dan Theodoridis (2009) menyebutkan ritel ini memiliki standar tertentu 
dalam operasionalnya. Bentuk bisnis ritel modern diantaranya minimarket dan supermarket.

Hasil penelitian Saddewisasi, Ariefiantoro, dan Santoso (2011) membuktikan bahwa ritel modern mampu mengambil alih pangsa pasar ritel tradisional. Maknanya ritel modern memiliki keunggulan tertentu yang tidak dimiliki oleh ritel tradisional atau nilai-nilai unggul yang ada pada ritel modern, lebih disukai oleh masyarakat dimana mereka berada. Penelitian Adiba (2016) juga menjelaskan suasana toko dan lokasi ritel modern sebagai daya tarik konsumen. Sedangkan Fitriana (2016) menemukan bahwa display interior yang menarik, mempengaruhi konsumen untuk membeli hal-hal yang tidak direncanakan pada ritel modern. Artinya ada nilai-nilai tertentu membuat mereka unggul dari ritel tradisional atau ada faktor kunci dan menjadi daya tarik tersendiri, sehingga konsumen beralih menjadi konsumen ritel modern.

Permasalahannya sekarang bagaimana ritel-ritel tradisional dan ritel modern yang dimiliki oleh masyarakat umum bisa bersaing dengan ritel modern milik kelompok usaha besar. Salah satu solusinya adalah mereka mengadopsi nilai-nilai unggul ritel modern milik kelompok perusahaan besar dan memodifikasi sesuai kebutuhannya. Untuk itulah diperlukan penelitian ini.

\section{Ritel}

\section{Kajian Teori}

Ritel atau bisnis eceran ataupun penjualan eceran merupakan mata rantai saluran distribusi barang, ia termasuk kegiatan perdagangan yang menyediakan komuditas untuk konsumen akhir, dilaksanakan secara tradisional maupun modern (Alma, 2014; Ayers \& Odegaard, 2018; Dwiyananda, Martha, \& Mawardi, 2015; Foster, 2008; Perpres RI No 112, 2007; Sujana, 2012), seperti: toko, supermarket dan minimarket.

Ritel berfungsi memenuhi kebutuhan masyarakat melalui penjualan barang-barang kebutuhan konsumen ataupun jasa untuk keperluan pribadi dan masyarakat umum. Utami (2006: 10) menyebutkan fungsi dari ritel diantaranya: menyediakan barang, membagi/split barang, penyimpan barang, penyedia jasa, meningkatkan nilai barang. Disamping itu ritel modern juga berfungsi sebagai pengendali harga barang dan pengendali distribusi barang (Sujana, 2012; Utomo, 2009), penyedia barang (Aulia S, Elmanisa, \& Gunawan, 2009). Masing-masing fungsi ritel modern dirangkum sebagai: penyedia berbagai barang/jasa dan kebutuhan masyarakat, split barang menjadi ukuran kecil, penyimpanan persediaan, meningkatkan nilai tambah barang/jasa, pengendali harga, pengendali distribusi barang pada masyarakat.

\section{Ritel Tradisional dan Ritel Modern}

Penelitian ini fokus pada ritel modern. Meskipun demikian pembaca perlu mengetahui ritel tradisional. Ritel tradisional dan ritel modern memiliki fungsi yang sama sebagai penyalur barang ke konsumen akhir, namun keduanya memiliki perbedaan. Ada beberapa kriteria ritel tradisional, diantaranya: tempat tidak telalu luas, barang dagang tidak lengkap, kurang nyaman, harga bisa di tawar, tidak semua barang dagang dipajang (Rozinawati \& Purwata, 2010), penjual dan pembeli berkomunikasi secara langsung, dilayani langsung oleh pemilik, belum menggunakan teknologi pembayaran dan tidak memiliki standar baku (Chaniago, 2018). Bentuk ritel tradisional berupa: toko-toko, warung, outlet yang menjual kebutuhan konsumen. Sebaliknya ritel modern, ia dijalankan oleh pengusaha yang memiliki modal cukup besar, contoh: minimarket/modern shop, supermarket, hypermarket.

Kriteria dan karakteristik ritel modern diantaranya: lokasi strategis, suasana toko nyaman (Adiba, 2016), display interior menarik (Fitriana, 2016), nyaman, bersih, harga bersaing, strategis (Nurdiani, 2010), supply chain terjamin, inventory, inovasi produk (Ayers \& Odegaard, 2018), pelayanan profesional (Najib \& Sosianika, 2017), fasilitas lengkap, terpusat pada satu gedung, modal besar, layout tertata, aman dan nyaman, menggunakan teknologi dan konsumen selfservice (Dimyati, 2015). Para peneliti telah membuktikan bahwa ritel modern lebih unggul dari ritel tradisional (Hubeis, 2012; Kusnadi, 2013; Noor, 2013; Rahayuningrum \& Widyanti, 2007; Saddewisasi et al., 2011; Sihombing, 2013).

Ritel modern sebahagian ada yang dimiliki oleh perorangan (independent retail firm) dan ada yang dimiliki oleh kelompok perusahaan besar atau dibawah koordinasi suatu perusahaan sebagai induknya. Biasanya perusahaan induk dari bisnis ritel menciptakan sistem pengelolaan dan standar operasional yang sudah baku, sehingga setiap ritelritel dibawah mereka akan menjalankan kegiatan bisnis dengan standar dan kualitas yang seragam. Panigyrakis dan Theodoridis (2009) menemukan bahwa faktor kunci keberhasilan ritel ada pada standard operating procedure dan kebijakan internal perusahaan. Artinya pada ritel modern tidak ada pelayanan yang berbeda atau pemenuhan kebutuhan masyarakat dilaksanakan dengan standar tertentu dan nilai-nilai unggul tertentu.

Saat tulisan ini dibuat (2019), cukup banyak informasi pada berbagai media Massa yang menjelaskan dampak negatif ritel modern pada ritel tradisional (Aulia S et al., 2009; Prihatna, 2013; Saddewisasi et al., 2011). Disatu sisi ritel modern 
tidak disukai, tetapi disisi lain masyarakat makin banyak yang pindah berbelanja menjadi konsumen minimarket/ritel modern.

Terlepas dari fakta di atas, tentu ada faktor-faktor yang menjadi nilai unggul dari ritel modern tersebut. Nurdiani (2010) menyatakan keunggulan ritel modern, yaitu nyaman (bersih dan aman), harga bersaing, lengkap dan mudah terjangkau. Pendapat di atas bisa disimpulkan bahwa faktor kunci unggulnya ritel modern hanya dari fisik (nyaman, aman, bersih), harga barang dan lokasi strategis. Ayers dan Odegaard (2018) menemukan bahwa kesuksesan dalam ritel modern ditentukan oleh pengelolaan keuangan, barang dagang dan penentuan anggaran/biaya, supply chains dan inventory serta inovasi produk dagangan. Sedangkan Colla dan Lapoule (2012) membuktikan bahwa strategy marketing, relationship marketing, purchasing, e-marketing (ergonomics, assortment and price policy), logistic strategy and service yang menentukan keberhasilan ritel. Hal yang hampir sama ditemukan oleh McKenzie (2006), ia membuktikan faktor kunci keberhasilan ritel modern fokus pada kualitas layanan, harga, aspek fisik (tampilan dan layout toko), media informasi dan staf yang profesional. Beberapa hasil penelitian lain juga mengungkap faktor kunci keberhasilan ritel modern ditentukan oleh inovasi, strategi, teknologi, supplier, kualitas layanan dan SDM yang profesional (McKenzie, 2006; Megicks, 2007; Reynolds, Howard, Cuthbertson, \& Hristov, 2007; Sorescu, Frambach, Singh, Rangaswamy, \& Bridges, 2011; Swoboda, Haelsig, Morschett, \& Schramm-Klein, 2007; Tsironis, Gotzamani, \& Mastos, 2016). Inovasi, strategi dan kualitas layanan sangat tergantung pada ketersediaan SDM dan supervisor minimarket.

Secara literatur review ada sepuluh faktor kunci keberhasilan pengelolaan ritel modern seperti: strategi, inovasi, aspek fisik (tampilan, tata letak dan lokasi), kelengkapan barang, supplier dan inventory, harga barang, teknologi, media informasi, kualitas layanan dan keuangan. Melihat uraian dan temuan dari para peneliti di berbagai negara bervariasi dalam menentukan faktor kunci keberhasilan pengelolaan ritel modern, maka diperlukan penelitian yang holistik, guna menginvestigasi faktor kunci keberhasilan bisnis di ritel modern dan dapat diterapkan untuk Indonesia. Kesepuluh faktor kunci di atas memiliki korelasional seperti gambar 1.

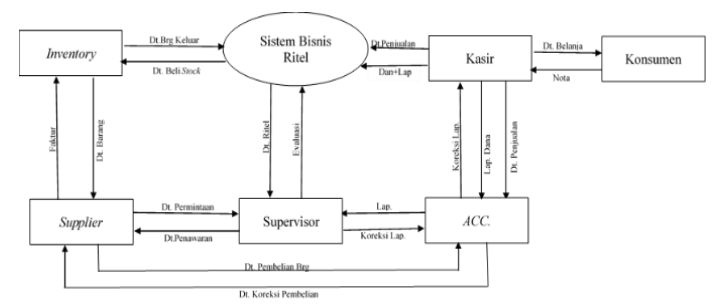

Gambar 1. Relasional Sistem Bisnis Ritel Minimarket Sumber: Studi literatur

Gambar 1 mendeskripsikan bahwa konsep sistem bisnis di ritel modern memiliki keterkaitan dengan fungsi inventory, supplier, supervisor, sistem pembayaran/kasir dan sistem pencatatan (ACC/accounting). Sepuluh faktor kunci keberhasilan ritel berjalan didalam fungsi-fungsi tersebut. Seorang pemilik ritel membutuhkan strategi, seperti dalam penentuan: inventory, supplier, sistem pencatatan/accounting, siapa yang menjadi kasir serta karyawan. Strategi yang dibuat harus berdampak pada meningkatnya penjualan dan timbulnya kepercayaan konsumen pada ritel yang bersangkutan. Strategi dijalankan oleh pemilik ritel bersama-sama dengan supervisor ritel. Pemilik dan supervisor mengaplikasikan dan mendorong tumbuhnya inovasi pada semua SDM yang menjalankan ritel seperti: mengendalikan kelengkapan barang, harga, teknologi yang dipakai, media promosi, keuangan dan pelayanan yang bermutu. Konsep dari 10 faktor keberhasilan ritel modern ini, dapat diwujudkan dalam bentuk software minimarket, kami menamakannya dengan aplikasi bisnis ritel.

\section{Metode Penelitian}

Objek penelitian ini adalah faktor penentu yang menjadi daya tarik bagi konsumen untuk mau berbelanja di ritel modern. Faktor ini merupakan suatu prestasi atau keberhasilan yang dimiliki oleh masing-masing ritel modern. Sedangkan subjek penelitian adalah para konsumen yang berbelanja di ritel modern.

Penelitian ini menggunakan metode deskriptif dengan pendekatan kuantitatif. Data-data diambil dilapangan pada berbagai ritel modern di Kota Cimahi dengan menggunakan kuesioner, observasi dan data sekunder berasal dari Pemda Cimahi.

\section{Populasi dan Sampel}

Populasi penelitian ini adalah seluruh masyarakat Kota Cimahi dengan kriteria: tinggal di area ritel modern/minimarket berjarak maksimal $200 \mathrm{~m}$, berusia dewasa (diatas 21 th), pernah berbelanja minimal 3 kali. Dari hasil perhitungan dengan menggunakan rumus Slovin diperoleh jumlah sampel yang diambil 400 responden. Namun data yang terkumpul dan layak untuk diolah hanya 388 responden.

Mayoritas responden berusia produktif dengan tingkat pendidikan SMA - Sarjana, tingkat penghasilan termasuk pada kriteria rendah. Sedangkan rata-rata daya beli mereka setiap ke 
minimarket/ritel modern antara Rp $50.000-\mathrm{Rp}$ 100.000,-

\section{Operasional Variabel}

Mengacu pada teori di atas, maka operasionalisasi dari variabel yang diteliti disajikan pada tabel berikut:

Tabel 1

Operasional Variabel

\begin{tabular}{lll}
\hline Variabe & Faktor & Indikator \\
\hline & Strategi & $\begin{array}{l}\text { Jujur, terbuka, tidak mematikan } \\
\text { ritel sekitar, kemandirian, brand } \\
\text { lokal }\end{array}$ \\
& Inovasi & $\begin{array}{l}\text { Hadiah, kemasan, tersedia } \\
\text { produk baru, barang murah }\end{array}$ \\
& Aspek & Tampilan (menarik, bersih), tata \\
& fisik/Fasi & letak, lokasi strategis, brand \\
& itastitusi, parkir, ramah
\end{tabular}

Sumber: Kompilasi dari Ayers dan Odegaard

(2018); McKenzie (2006); Megicks (2007);

Nurdiani (2010); Reynolds et al. (2007); Sorescu et

al. (2011); Swoboda, Weindel, and Hälsig (2016);

Colla dan Lapoule (2012); Utami (2006).

Hasil uji validitas menunjukkan ada tiga indikator yang tidak valid, indikator yang tidak valid didrop/dibuang, sehingga total indikator ada 47.

\section{Hasil Penelitian dan Pembahasan \\ Hasil Penelitian}

Pengujian data dilakukan beberapa kali dengan menggunakan analisis faktor dan bantuan software SPSS, diperoleh informasi seperti disajikan pada tabel 2. Ada beberapa faktor baru yang terbentuk dan berbeda dengan teori yang dipakai. Faktor baru tersebut diberi label baru/nama baru.

Tabel 2.

Pengelompokkan Jawaban Responden Dari Analisis Faktor

\begin{tabular}{|c|c|c|c|}
\hline $\begin{array}{l}\mathbf{N} \\
\mathbf{0}\end{array}$ & Indikator & $\begin{array}{l}\text { Label } \\
\text { teoriti } \\
\quad \mathrm{S}\end{array}$ & $\begin{array}{c}\text { Label } \\
\text { Baru } \\
(\text { Temua } \\
\text { n) }\end{array}$ \\
\hline 1 & $\begin{array}{l}\text { Kecepatan, respon } \\
\text { karyawan, keramahan, } \\
\text { pengetahuan, waktu } \\
\text { operasional }\end{array}$ & $\begin{array}{l}\text { Kualit } \\
\text { as } \\
\text { layana } \\
n\end{array}$ & $\begin{array}{l}\text { Profesio } \\
\text { nal } \\
\text { SDM }\end{array}$ \\
\hline 2 & $\begin{array}{l}\text { Jujur, produk-tidak } \\
\text { melanggar norma, hadiah, } \\
\text { tidak mematikan ritel } \\
\text { sekitar, produk segar, } \\
\text { ramah lingkungan. }\end{array}$ & & $\begin{array}{l}\text { Strategi } \\
\text { bisnis } \\
\text { ritel }\end{array}$ \\
\hline 3 & $\begin{array}{l}\text { Transaksi aman, } \\
\text { pembayaran dikasir } \\
\text { sederhana, hemat tenaga } \\
\text { kerja, ketepatan } \\
\text { menentukan harga jual, } \\
\text { biaya tambahan, } \\
\text { ketepatan perhitungan } \\
\text { transaksi }\end{array}$ & $\begin{array}{l}\text { Keuan } \\
\text { gan }\end{array}$ & $\begin{array}{l}\text { Jaminan } \\
\text { pembay } \\
\text { aran }\end{array}$ \\
\hline 4 & $\begin{array}{l}\text { Mesin kasir, bayar via } \\
\text { debit/kredit, cctv }\end{array}$ & $\begin{array}{l}\text { Tekno } \\
\text { logi }\end{array}$ & $\begin{array}{l}\text { Efektivit } \\
\text { as } \\
\text { Teknolo } \\
\text { gi } \\
\text { pembay } \\
\text { aran }\end{array}$ \\
\hline 5 & $\begin{array}{l}\text { Barang lengkap, inventory } \\
\text { tersedia, variasi kualitas, } \\
\text { merek, harga bersaing, } \\
\text { kemasan. }\end{array}$ & - & $\begin{array}{l}\text { Mercha } \\
\text { ndise \& } \\
\text { Assortm } \\
\text { ent }\end{array}$ \\
\hline 6 & $\begin{array}{l}\text { Tampilan bersih, tampilan } \\
\text { menarik, tata letak, } \\
\text { tersedia produk baru }\end{array}$ & - & $\begin{array}{l}\text { Tampila } \\
\mathrm{n} \text { fisik } \\
\text { ritel }\end{array}$ \\
\hline 7 & $\begin{array}{l}\text { Media brosur, tv, } \\
\text { banner/spanduk }\end{array}$ & $\begin{array}{l}\text { Media } \\
\text { inform } \\
\text { asi/ } \\
\text { promo } \\
\text { si }\end{array}$ & $\begin{array}{l}\text { Media } \\
\text { promosi }\end{array}$ \\
\hline 8 & $\begin{array}{l}\text { Pencantuman harga, } \\
\text { konten informasi, } \\
\text { discount, supplier } \\
\text { dipercaya. }\end{array}$ & - & $\begin{array}{l}\text { Komuni } \\
\text { kasi } \\
\text { dipercay } \\
\text { a }\end{array}$ \\
\hline 9 & $\begin{array}{l}\text { Brand institusi, parkir, } \\
\text { lokasi strategis }\end{array}$ & & $\begin{array}{l}\text { Citra } \\
\text { ritel }\end{array}$ \\
\hline 10 & $\begin{array}{l}\text { Internet, informasi jujur, } \\
\text { kecepatan kasir, terbuka. }\end{array}$ & - & $\begin{array}{l}\text { Custome } \\
r \text { Service }\end{array}$ \\
\hline
\end{tabular}


Secara grafis faktor yang terbentuk dan menjadi dasar keberhasilan ritel modern digambarkan sebagai berikut:

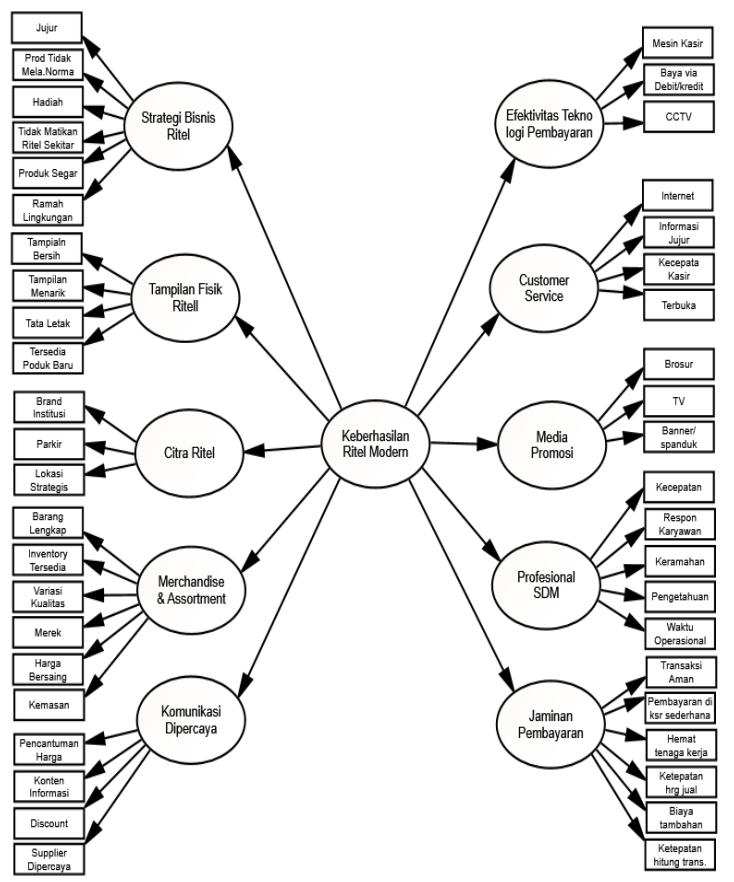

Gambar 2: Labeling dan Faktor yang Menentukan Keberhasilan Ritel Modern

Sumber: Hasil penelitian, 2019

\section{Pembahasan}

Temuan Swoboda et al. (2016) menginformasikan ada peran yang bervariasi dari atribut ritel. Masingmasing ritel, atribut unggulannya tidaklah sama. Penelitian ini menemukan 10 atribut/faktor yang menentukan ritel modern berhasil dalam menjalankan bisnisnya. Empat dari 10 faktor tersebut similar dengan temuan peneliti terdahulu seperti: profesional SDM/kualitas layanan (McKenzie, 2006; Najib \& Sosianika, 2017; Swoboda et al., 2007), Jaminan pembayaran/keuangan (Ayers dan Odegaard, 2018), efektivitas teknologi pembayaran/teknologi (Dimyati, 2015; Dupuis \& Prime, 1996; Sorescu et al., 2011), media promosi (Colla \& Lapoule, 2012; McKenzie, 2006). Dari 10 faktor, enam adalah faktor baru yang terbentuk yaitu: strategi bisnis ritel, merchandise \& assortment, tampilan fisik ritel, komunikasi dipercaya, citra ritel dan customer service. Baskaran (2011) dalam penelitiannya menyimpulkan ada enam faktor penentu keberhasilan ritel modern, yaitu: efficient supply chaints, abilty to penetrate rural market, leveraging technology, customized solutions, store brand, Custumer relantionship management. Tiga dari temuannya (leveraging technology, store brand, custumer relantionship management) similar dengan penelitian ini yaitu efektivitas teknologi pembayaran, customer service, sedangkan store toko/brand institusi sub dari citra toko.

Strategi bisnis adalah siasat yang dijalankan oleh manajemen perusahaan (dalam hal ini manajemen ritel modern) untuk mencapai tujuan perusahaan. Hampir semua bisnis memerlukan strategi, begitu juga dalam menjalankan ritel. Megicks (2007) telah membuktikan strategi sebagai sebuah faktor penting meningkatkan kinerja ritel. Strategi untuk ritel itu kami namakan strategi bisnis ritel. Strategi bisnis ritel agak lebih spesifik dan fokus pada siasat bagaimana menarik orang agar mau menjadi konsumen, seperti berorientasi pada: prinsip kejujuran dalam bertransaksi dengan konsumen, menjual produk yang segar, ramah lingkungan dan tidak melanggar norma, mau berbagi dengan memberikan hadiah, bisnis yang tidak mematikan ritel sekitar. Kljenak, Lukic, dan Kvrgic (2012) penelitiannya menyarankan praktik strategi yang mengacu pada ramah lingkungan efektif mencapai tujuan ritel. Orientasi ramah lingkungan sebaiknya dikombinasikan dengan prinsip kejujuran, menjual produk berkualitas, taat pada Norma setempat, mau membagi keuntungan dan menjaga kehidupan ritel lainnya.

Merchandise \& assortment juga menjadi faktor penentu seorang konsumen mau berbelanja di ritel modern. Barang dagang yang lengkap, tersedia berbagai variasi dan kualitas merupakan faktor penting bagi konsumen (Dahab, Su, Riolli, \& Marquardt, 1997). Faktor ini menjadi salah satu faktor yang penting dan membuat orang mau menjadi konsumen di ritel terkait. Penjelasannya konsumen tidak suka berbelanja berpindah-pindah dari satu ritel ke ritel lain, karena akan membuang waktu mereka.

Tampilan fisik ritel adalah ujud fisik ritel yang dapat dinikmati oleh panca indra konsumen seperti: ritel terlihat bersih, enak dilihat, barang ditata dengan menarik dan menyajikan produk baru yang mudah dilihat. Temuan Fitriana (2016) dan Cornelius, Natter, dan Faure (2010) memperkuat hasil penelitian ini, bahwa display interior yang menarik mempengaruhi konsumen melakukan pembelian. Sementara itu Nurdiani (2010) menemukan ritel yang bersih dan aman disukai konsumen. Temuan penelitian tersebut semakin memperjelas bahwa tampilan fisik sebuah ritel turut menjadi pertimbangan bagi orang-orang untuk mau berbelanja di ritel modern.

Komunikasi yang dipercaya meliputi kepercayaa konsumen pada apa yang dikomunikasikan, seperti dalam: mencatumkan harga pada barang dagang, isi informasi memiliki nilai bagi konsumen, discount yang nyata (tidak menaikan harga kemudian diberi discount) dan supplier bisa dipercaya oleh 
masyarakat (tidak memproduksi barang illegal, curang dan merugikan orang banyak). Luceri, Sabbadin, dan Zerbini (2017) penelitiannya menghasilkan empat faktor keberhasilan pengusaha kecil ritel yaitu: komunikasi, pertumbuhan, reaktivitas, dan diferensiasi. Komunikasi dan diferensiasi temuannya mirip dengan komunikasi dipercaya dan barang dagang yang lengkap di penelitian ini.

Citra ritel menunjukkan kepercayaan konsumen atas prestasi yang dimiliki untuk memuaskan kebutuhan konsumen, ia terkait pada barang dagang, fisik toko, lokasi, fasilitas, merek toko/brand institusi dan SDM yang profesional. Merek toko yang syah dan dapat dipercaya, pada jangka panjang mampu membangun citra ritel (Collins-Dodd \& Lindley, 2003; Kennedy, Kapitan, \& Soo, 2016). Agar ia memiliki citra positif, para peneliti telah membuktikan bahwa perusahaan yang fokus pada lokasi toko, kualitas produk, (Jimisiah J, 2016; Xhema, Metin, \& Groumpos, 2018), harga produk (Xhema et al., 2018), fasilitas, proses, dan nilai uang akan menentukan keberhasilannya (Jimisiah J, 2016). Sedangkan hasil penelitian ini menemukan bahwa citra ritel terbentuk dari beberapa hal seperti: lokasi yang strategis, memiliki tempat parkir dan brand institusi/merek toko. Citra ritel yang positif menambah keyakinan seseorang untuk mau berbelanja di ritel tersebut.

Customer service merupakan pelayanan yang diberikan oleh suatu ritel kepada konsumen seperti: fasilitas komunikasi, isi informasi jujur, kecepatan kasir dalam melayani setiap pembeli dan keterbukaan tentang mutu barang, harga dan hal-hal yang terkait pada kebutuhan konsumen. Beberapa penelitian (Colla \& Lapoule, 2012; Koistinen \& Järvinen, 2016) menyelidiki bahwa customer service memberikan rasa aman dan nyaman konsumen ketika berbelanja. Peran customer service juga penting sebagai salah satu faktor pendorong orang datang berbelanja.

Panigyrakis dan Theodoridis (2009) pada penelitiannya menyimpulkan bahwa faktor kunci keberhasilan ritel ada pada standard operating procedure dan kebijakan internal perusahaan. Namun penelitian ini membuktikan lain, kami menemukan 10 faktor penentu keberhasilan ritel modern, tidak ada bukti-bukti yang mendukung bahwa standard operating procedure dan kebijakan internal perusahaan menentukan keberhasilan ritel modern dipenelitian ini. Temuan lainnya memberikan penjelasan bahwa faktor efektivitas teknologi pembayaran dan tampilan fisik ritel merupakan faktor dominan keberhasilan usaha ritel modern. Efektvitas penggunaan teknologi pembayaran dirasakan oleh konsumen saat transaksi pembayaran seperti: kemudahan membayar tunai melalui mesin kasir, Bayar via kartu debit/kredit dan adanya kamera pemantau (CCTV) menimbulkan rasa aman bagi konsumen. Tampilan fisik ritel seperti: tampilan yang bersih, menarik, tata letak barang yang mudah dicari dan tersedianya barang baru menjadi faktor kedua terpenting bagi konsumen. Faktor ini memiliki kemiripan dengan temuan Blut, Teller dan Floh (2018) yang menjelaskan bahwa manajemen produk dan merek menampilkan efek terkuat pada keberhasilan ritel. Informasi lain yang kami temukan adalah konsumen menyukai barang yang berkualitas, produk baru dan disajikan secara menarik pada tempat yang mudah dicari. Hal itu menjelaskan pada kita bahwa barang yang berkualitas dan disajikan pada tempat yang strategis lebih disukai konsumen.

Hal lain yang ditemukan adalah strategi bisnis ritel, citra ritel, merchandise \& assortment, komunikasi dipercaya, customer service, media promosi, profesional SDM, jaminan pembayaran bukan menjadi penentu utama keberhasilan ritel modern. Media promosi menjadi faktor yang paling rendah dinilai oleh konsumen dalam menentukan keberhasilan ritel modern. Penyebabnya media promosi yang dipakai seperti brosur, iklan di tv dan spanduk kurang menarik perhatian konsumen. Guissoni, Sanchez, dan Rodrigues (2018) juga membuktikan bahwa manfaat promosi tergantung kondisi ekonomi dan kondisi masing-masing pasar ritel. Meskipun media promosi sebagai faktor yang tidak dominan menentukan keberhasilan pada ritel modern, tetapi ia turut berkontribusi. Riset Morimura dan Sakagawa (2018) menjelaskan promosi memiliki efek positif pada kinerja bisnis. Para peritel disarankan menyesuaikan bauran promosi mereka dengan kebutuhan strategis masing-masing ritel (Shyan \& Merrilees, 1998).

\section{Kesimpulan}

Penelitian ini menemukan 10 faktor penentu keberhasilan ritel modern di Indonesia. Faktor efektivitas penggunaan teknologi pembayaran dan tampilan fisik toko merupakan faktor dominan seseorang mau berbelanja di ritel. Rupanya konsumen Indonesia menginginkan kenyamanan, keamanan, kecepatan dan akurasi yang tinggi saat pembayaran. Penyebab faktor lain tidak dominan, karena semua ritel/toko sudah memiliki dan melaksanakannya dengan standar yang hampir sama. Kami menyarankan pada peneliti, bahwa penelitian ini perlu dilanjutkan dengan melihat dan menganalisis dari sisi konsumen dan pengelola ritel.

\section{Daftar Pustaka}

A. Adiba. (2016). Pengaruh Suasana Toko dan Lokasi Terhadap Minat Beli Konsumen Pada Toko Aurora Shop Samarinda. eJournal 
Administrasi Bisnis, 4 (3), 670-682. Retrieved from ejournal.adbisnis.fisip-unmul.ac.id

B. Alma, B. (2014). Kewirausahaan Untuk Mahasiswa dan Umum. Bandung: Alfabeta.

C. Aulia S, A., Elmanisa, A. M., \& Gunawan, M. P. (2009). Pola Distribusi Spasial Minimarket di Kota-kota Kecil. Jurnal Perencanaan Wilayah dan Kota, 20 No. 2, 78-94.

D. Ayers, J. B., \& Odegaard, M. A. (2018). Retail supply chain management, Second Edition. 6000 Broken Sound Parkway NW, Suite 300: CRC Press Taylor \& Francis Group.

E. Baskaran, K. (2011). The FDI permit for multi brand retail trading in India - Green signal or Red signal. International Journal of Asian Social Science,, 1(3), , 52-64.

F. Blut, M., Teller, C., \& Floh, A. (2018). Testing Retail Marketing-Mix Effects on Patronage: A Meta-Analysis. Journal of Retailing 94 (2) 113-135 doi:10.1016/j.jretai.2018.03.001

G. Chaniago, H. (2018). Faktor Penentu Keberhasilan Ritel Tradisional di Cimahi (Laporan Penelitian). Retrieved from Bandung:

H. Colla, E., \& Lapoule, P. (2012). E-commerce: exploring the critical success factors. International Journal of Retail \& Distribution Management, 40 (11), 842 - 864.

I. Collins-Dodd, C., \& Lindley, T. (2003). Store brands and retail differentiation: the influence of store image and store brand attitude on store own brand perceptions. Journal of Retailing and Consumer Services, 10 (6), 345-352. doi:10.1016/s0969-6989(02)00054-1

J. Cornelius, B., Natter, M., \& Faure, C. (2010). How storefront displays influence retail store image. . Journal of Retailing and Consumer Services, $\quad$ 17(2), 143-151. doi:10.1016/j.jretconser.2009.11.004

K. Dahab, D. J., Su, W., Riolli, L., \& Marquardt, R. (1997). Shoping Albanian Markets: Customer Satisfaction and Retail Strategy International Journal of Commerce and Management, 7(1 ), 29 - 56.

L. Dimyati, M. (2015). Persepsi Konsumen Terhadap Bauran Ritel Tradisional dan Modern di Kota Jember. Jurnal Ilmiah Relasi, XI No. 2, 175-196

M. Dupuis, M., \& Prime, N. (1996). Business distance and global retailing: a model for analysis of key success/failure factors. International Journal of Retail \& Distribution Management, 24(11), 30 - 38.

N. Dwiyananda, Martha, O., \& Mawardi, I. (2015). Pengaruh Produk, Harga, Tempat, Proosi Ritel Modern terhadap Keberlangsungan Usaha Ritel Tradisional di Gresik. JESTT (Jurnal Ekonomi Syariah Teori \& Terapan), 2 No. 9 September 2015. .
O. Fitriana, A. (2016). Analisis Pengaruh Display Interior Terhadap Perilaku Pembelian Impulsif Konsumen Indomaret Pontianak. Journal of Applied Intelligent System, 1, No.2, Juni 2016, $90-102$.

P. Foster, B. (2008). Manajemen Ritel. Bandung: Alfabeta.

Q. Guissoni, L. A. a., Sanchez, J. M., \& Rodrigues, J. M. (2018). Price and in-store promotions in an emerging market. Marketing Intelligence \& Planning, 36(4), 498-511. doi:10.1108/mip-08-2017-0154

R. Hubeis, M. (2012). Manajemen ritel kreatif dan inovatif dalam bisnis Bogor: Inti-prima.

S. Jimisiah J, N. T. K., Khairul Firdaus A, Sallaudin SH4, M.Mansor S. 2016. (2016). Critical Success Factors of Retail and Wholesale Industry: A Case Study. International Journal of Supply Chain Management IJSCM, 5, No. 2, June 2016, 94100.

T. Kennedy, A.-M., Kapitan, S., \& Soo, S. (2016). Eco-warriors: Shifting sustainable retail strategy via authentic retail brand image. Australasian Marketing Journal (AMJ), 24 (2), 125-134. . doi:10.1016/j.ausmj.2016.03.001

$U$. Kljenak, D. V., Lukic, R., \& Kvrgic, G. (2012). Green Retail Sale as a Factor of Business Success Metalurgia International, XVII No. 11

V. Koistinen, K., \& Järvinen, R. (2016). Comparing perceived insecurity among customers and retail staff during service encounters. Journal of Retailing and Consumer Services, 31, 80-92. doi:10.1016/j.jretconser.2016.03.014

W. Kusnadi, D. (2013). Implementasi Kebijakan Penataan Ritel Tradisional dan Modern di Kota Jambi. Jejaring Administrasi Publik., V No. 1, $294-302$.

X. Luceri, B., Sabbadin, E., \& Zerbini, C. (2017). Innovation in Tradition: Key success factor on new entrepreneurs in the retail trade. International Business Research, Vol.10,No.12;2017.

Y. McKenzie, B. (2006). Retail service quality success factors in Estonia: a qualitative approach. Baltic Journal of Management, 1 (3), 352 - 369.

Z. Megicks, P. (2007). Levels of strategy and performance in UK small retail businesses. Management Decision, 45(3), 484 - 502.

AA. Morimura, F., \& Sakagawa, Y. (2018). Information technology use in retail chains: Impact on the standardisation of pricing and promotion strategies and performance. Journal of Retailing and Consumer Services 45 (2018), 81-89.

BB. Najib, M. F., \& Sosianika, A. (2017). Retail Service Quality in Indonesia: Traditional 
Market VS Modern Market. Academy of Marketing Studies Journal., 21( 2), 1-12.

CC. Noor, A. (2013). Perlindungan Terhadap Pasar Tradisional di Tengah Ekspansi Pasari Ritel Modern. . Economica., IV, Ed 2, 107 -119.

DD. Nurdiani, D. (2010). Rupiah Meriah Dari Bisnis Minimarket. . Jakarta: PPM

EE. Panigyrakis, G. G., \& Theodoridis, P. K. (2009). Internal marketing impact on business performance in a retail context. International Journal of Retail \& Distribution Management Vol. 37 No. 7, 2009 600-628.

FF. Perpres RI No 112. (2007). Tentang Penataan dan Pembinaan Pasar Tradisional, Pusat Perbelanjaan dan Ritel Modern.

GG. Prihatna, O. (2013). Analisis perbandingan ritel modern dan ritel tradisional dilihat dari 7P. Jurnal Forum Ilmiah, 10, No. 2 Mei 2013, $252-261$.

HH. Rahayuningrum, N., \& Widyanti, T. (2007). Kajian Dampak Ekonomi Keberadaan Hypermarket Terhadap Ritel/Pasar Tradisional. Buletil Ilmiah Litbang Perdagangan, 3-17.

II. Reynolds, J., Howard, E., Cuthbertson, C., \& Hristov, L. (2007). Perspectives on retail format innovation: relating theory and practice. International Journal of Retail \& Distribution Management, , 35(8), 647 - 660.

JJ. Rozinawati, \& Purwata. (2010). Modul Membuka Usaha Eceran/Ritel Untuk SMK dan $M A K$. Jakarta: Erlangga.

KK. Saddewisasi, W., Ariefiantoro, T., \& Santoso, A. (2011). Analisis Dampak Usaha Ritel Modern Terhadap Usaha Ritel Tradisional (Studi Kasus di Wilayah Kecamatan Gunungpati, Mijen, Tembalang dan Banyumanik). Jurnal Riptek, 5 No. 1, 2011, 31-43.

LL. Shyan, F. K., \& Merrilees, B. (1998). Exploring the relevance of strategic promotion management approach among small independent retailers. International Journal of Retail \& Distribution Management,, 26(9), 354-361. doi:10.1108/09590559810237890

MM.Sihombing, E. Y. (2013). Analisis Dampak Kehadiran Ritel Modern Terhadap Ritel Tradisional di Kota Medan. Jurnal Ekonomi dan Keuangan 1 No. 4 74-84.

NN. Sorescu, A., Frambach, R. T., Singh, J., Rangaswamy, A., \& Bridges, C. (2011). Innovations in Retail Business Models. Journal of Retailing, 87 S (1, 2011) S3-S16.

OO. Sujana, A. S. (2012). Manajemen Minimarket. Jakarta: Raih Asa Sukses.

PP. Swoboda, B., Haelsig, F., Morschett, D., \& Schramm-Klein, H. (2007). An intersector analysis of the relevance of service in building a strong retail brand Managing Service Quality: An International Journal, 17 (4), 428 -448 .

QQ. Swoboda, B., Weindel, J., \& Hälsig, F. (2016). Predictors and effects of retail brand equity A cross-sectoral analysis. Journal of Retailing and Consumer Services,, 31, 265-276. doi:10.1016/j.jretconser.2016.04.007

RR. Tsironis, L. K., Gotzamani, K., \& Mastos, T. D. (2016). e-Business critical success factors: towards the development of an integrated success model. Business Process Management Journal. Retrieved from https://doi.org/10.1108/BPMJ-02-2016-0030

SS. Utami, W. C. (2006). Manajemen Ritel. Jakarta: Salemba Empat.

TT. Utomo, T. J. (2009). Fungsi dan Peran Bisnis Ritel Dalam Saluran Pemasaran Jurnal Fokus Ekonomi, 4 No. 1 Juni 2009, 44-55.

UU. Xhema, J., Metin, H., \& Groumpos, P. (2018). Switching-Costs, Corporate Image and Product Quality effect on Customer Loyalty: Kosovo Retail Market. IFAC-PapersOnLine, 3, 51(30), 287-292. doi:10.1016/j.ifacol.2018.11.30 